\title{
AS ORDENAÇÕES FILIPINAS E O DIREITO AGRÁRIO
}

\author{
Olavo Acyr de Lima Rocha \\ Professor Associado da Faculdade de Direito da Universidade de São Paulo e \\ Professor Titular da Faculdade de Direito da Universidade São Judas
}

Resumo:

O autor objetiva, com seu trabalho, identificar nas Ordenações Filipinas, os institutos agrários, especialmente as Sesmarias e outros como os contratos agrários, com ênfase para os contratos de arrendamento e parceria rurais.

Abstract:

The author aims, at his work, refers in the portuguese Philippines Code the agrarian institutes, especially the incultivated lands institute and other like agrarian contracts with emphasis to renting and partnership contracts.

Unitermos: Ordenações Filipinas; instituto das Sesmarias e contratos agrários; aspectos.

\section{Sumário}

1. As Ordenações Reinícolas, seu tempo e conteúdo.

2. Os institutos de Direito Agrário, nas Ordenações Filipinas, em seu Livro IV

2.1. Título IX

2.2. Título XXVII

2.3. Título XXXVI
Da venda de coisa de raiz feita a tempo que já era arrendada ou alugada a outrem por tempo certo.

\section{Das sterilidades.}

Do que toma alguma propriedade de foro para si e certas pessoas, e não nomeou alguém a ela antes da morte.

2.4. Título XXXVII Das Nomeações que se fazem dos prazos, em que casos se podem revogar.

2.5. Título XXXVIII Do foreiro que alheou o foro com autoridade do senhorio ou sem ela. 
2.6. Título XXXIX Do foreiro que não-pagou pensão em tempo devido, e como purgará a mora.

2.7. Título XL Que se não aforem casas senão a dinheiro.

2.8. Título XLI Que os foreiros dos bens da Coroa, Morgados, Capellas ou Commendas, não dêem dinheiro nem outra cousa aos senhorios, por lhes aforarem ou novarem.

2.9. Título XLII Que não sejam constrangidas pessoas algumas a pessoalmente morarem em algumas terras ou casais.

2.10. Título XLIII Das Sesmarias.

2.11. Título XLV Do que da herdade a parceiro de meias ou a terço, ou quarto, ou arrenda por certa quantidade.

2.12. Título LXIX Que se não façam arrendamentos de gados ou colmêas.

\section{Conclusões}

4. Bibliografia

1. As Ordenações Reinícolas, seu tempo e conteúdo

Antes de abordarmos o tema acima, julgamos oportuno um ligeiro apanhado histórico, para que se possa ter uma idéia da época em que teve lugar a compilação de Leis, Alvarás, Cartas Régias e as próprias Ordenações, em um Código ou Codice bem como seu conteúdo.

Nos tempos da monarquia, não havia Código Geral pelo qual se administrasse a Justiça. Os costumes locais eram validados pelo Foral. ${ }^{1}$ Como já se analisou em trabalhos relativos à época, os nobres criavam-se isenções; o clero se munia de regalias e o poder real buscava tornar-se cada vez mais forte, publicando leis avulsas, que nem sempre tinham boa acolhida, mormente se feriam imunidades locais ou tendiam à diminuição dos privilégios da clerezia. Por outro lado, as desordens internas e as guerras com estranhos mal ensejavam se codificassem Leis, emergentes em ocasiões normais e que o costume levava a ab-rogar.

1. Códice ou Carta que os monarcas concediam às terras contendo as leis municipais de uma cidade, conselho ou julgado, com os scus direitos e privilégios e que regulava o modo de administrar e pagar tributos. (Lello Universal - Novo Dicionário Enciclopédico Luso-Brasilciro - Porto). 
Há que destacar, por outro lado, que até o século XVI, o Direito Romano era a fonte do Direito Comum na Europa. Por sua amplitude, origem e antigüidade, tinha enorme prestígio. Era o Direito Comum o principal objeto da jurisprudência na solução dos casos concretos.

Seus princípios eram, inclusive, aplicados às espécies ordinárias, as mais comuns. Também o Direito Canônico era prestigiado. O Romano favorecia o absolutismo dos imperadores e o Canônico o poder do pontífice e as prerrogativas do clero. As Leis Nacionais não eram ensinadas nas universidades e os jurisconsultos não procuravam fixar nas Ordenações os princípios e sistemas jurídicos. Mesmo quando havia necessidade de interpretar Leis Nacionais, os praxistas, que escreviam os usos do Foro, utilizavam os princípios do Direito Romano e Canônico, muito embora as leis em questão acolhessem antigos costumes e peculiaridades da própria nação.

Por Ordenações entendiam-se os Alvarás, as Cartas Régias, as Leis. Alguns desses atos se denominavam Ordenação e Lei.

Depois de Aljubarrota, ${ }^{2}$ foi preciso consolidar o poder real e D. João I comete a tarefa de unificar as Leis ao corregedor de sua Corte, o doutor João Mendes, sucedido no cargo, no reinado seguinte, pelo doutor Ruy Fernandes, do Conselho do Rei, que reuniu leis e outros atos dispersos.

Há quem diga que D. João cometera a tarefa da compilação a João Das Regras, que bons serviços prestara ao Mestre de Aviz, nas cortes de Coimbra. No prefácio das Ordenações Manuelinas, Edição Coimbra, 1797. contudo, apenas se menciona o nome do corregedor João Mendes, como realizador ou iniciador da primeira compilação. $^{3}$

O trabalho então determinado, de compilação dos textos, segundo uma fórmula clara e metódica, só foi concluído em 1446, em 28 de julho, na "Vila da Arruda" no reinado de D. Afonso V. regência do infante D. Pedro. Esse Códice ou Coleção Sistematizada de Leis e outros atos ficaram então conhecidos como

2. Vitória decisiva de D. João ] de Portugal contra D. Joăo I de Castella, em 14 de agosto de 1385 , um dos mais gloriosos acontecimentos da história portuguesa, em memória do qual Coi erigido 0 grandioso Convento da Batalha. Praticaram-se prodígios de valor. Uma pequena hoste de portugueses conseguiu levar de vencida o exército inimigo 4 ou 5 vezes mais numeroso. Notáveis a ação do rei c do condestável D. Nuno Álvares Percira. (Lello Universal - Novo Dicionário Luso-Brasileiro - Porto).

3. Ordenações do Reino - Edições do Século XVI por Tito de Noronha - Ernesı Chardron Porto, 1871. 
Ordenações Afonsinas, e foi publicado em 1446, ou segundo alguns, em 1447, após trabalhos de revisão. ${ }^{4}$

A divisão das Ordenações em cinco Livros segue as Decretais de Gregório IX. Os Livros são subdivididos em Títulos.

Em 1505, mandou D. Manuel I rever o Código anterior. Nas novas Ordenações, seguiu-se a mesma ordem e divisão, além de importantes aditamentos e supressões. Foram publicadas de 1512 a 1521, tornando-se conhecidas como Ordenações Manuelinas.

Logo no princípio de seu reinado determinou Felipe II (Felipe I, de Portugal) reformar as Ordenações Manuelinas. Consistiu a reforma, principalmente, em aditamentos, sendo de pouca importância as alterações. Foram publicadas em 1603, e confirmadas em 1643. Constituiu-se ela, praticamente, no cerne do Direito Civil português até a promulgação de seu Código Civil. Vale destacar, que o surgimento das Ordenações Afonsinas, em 1446, constituiu acontecimento notável na legislação dos povos cristãos. Até porque, todos os outros códigos europeus the são posteriores.

Jeremias Bentham, na obra Vista Geral de um Corpo Completo de Legislação, assegura que os Códigos mais antigos da Europa são o dinamarquês de 1683, o sueco de 1734, o Frederico ou Prussiano, de 1751 e o sardo, de 1770. Antes do dinamarquês, já em Portugal, haviam sido publicados três Códigos completos e um incompleto, o Sebastiânico.

As Ordenações Filipinas criaram uma nova época para a ciência jurídica de Portugal e, por conseqüência, para a do Brasil.

O fundo dessa legislação, no dizer de Coelho Sampaio, pelo que pertence ao Direito particular é todo de eqüidade; nela se acha o Direito Romano, entendido segundo a Glosa, no que o mesmo tem de melhor.

4. Costa, Mário Júlio de Almeida. História do Direilo Português, p. 274. Ed. Almedina, Coimbra, 1999 
2. Os institutos de Direito Agrário, nas Ordenações Filipinas em seu livro IV.

Segundo nosso entendimento e conceito:

Direito agrário é o conjunto de princípios e de normas destinadas a reger as relações econômicas e sociais pertinentes à atividade, às pessoas e aos bens rurais, de forma a assegurar o atendimento da função social e a conservação da terra e demais recursos naturais renováveis"

Muito embora a expressão função social da terra possa ter uma conotação moderna, desvinculada de qualquer conceito que poderia eventualmente vigir à época que, em Portugal, foi levada a efeito a consolidação ou compilação em referência, o fato é que a apresentação de seus textos e respectiva apreciação poderão, mais adiante, modificar essa impressão. Se isso ocorrer, mais uma vez teremos uma demonstração do gênio português e do seu pioneirismo histórico marcảdo já pela elaboração dos primeiros Códices da Europa.

Isto posto, passaremos a analisar, com menção aos respectivos Títulos, a matéria inserida nas Ordenações Filipinas e que, segundo nosso entender, constitui Direito Agrário. Assim é que, no Título IX, encontramos:

\subsection{Título IX}

Da Venda de coisa de raiz feita a tempo que já era arrendada ou alugada a outrem por tempo certo. ${ }^{5}$

5. A matéria de locação de imóveis se acha no nosso Direito atual regulada no Capítulo IV, do Título V, do Livro III, do Código Civil, Seção I, hoje Lei n. 8.245, de 18.10.91, que trata da locação urbana, incluindo a comercial com a proteção do fundo de comércio. A locação dos próprios da Nação regula-se pelo Dec. Lei n. 9.760, de 05.09.46. Em seu art. 1.197, o Código Civil cslabclece que, se durante a locação for alienada a coisa, nāo licará o adquirente obrigado a respcitar o contrato, se nele não for consignada a cláusula de sua vigência no caso de alienação, e constar de registro público. Para os prédios rústicos, por sua vez, o art. 1.209 do Código Civil, estabelece un prazo de 6 meses para a desocupação do imóvel locado, se for imóvel rústico ou rura], prazo esse repetido pelo Dec. Lei n. 4, de 07.02.66. Quando sc trata de imóvel rural, isto é, destinado a atividades agrárias, a matéria se acha contemplada na Lei n. 4.504, de 30.11.64. em seu Capílulo IV Do Uso ou da Posse Temporária da 
Nesse título, as Ordenações Filipinas fixavam normas destinadas a regular as relações entre o proprietário de bens imóveis, inclusive Herdades, quando arrendados se acharem, ao tempo da venda. Estabelece-se, então, que no arrendamento a prazo de menos de dez anos, com posse já transmitida ao arrendatário, não fica o comprador obrigado a manter o contrato, podendo demandar o rendeiro ou alugador a deixar o imóvel.

Tal regra, no entanto, admite exceção quando, no contrato de venda e compra se tiver estabelecido o cumprimento do contrato de arrendamento pelo comprador ou, se este, depois da venda, tiver consentido de alguma maneira no cumprimento do contrato pelo rendeiro ou, se o vendedor no contrato de arrendamento obrigou geral ou especialmente a cousa arrendada para cumprimento do contrato. ${ }^{6}$

Em cada um desses casos, o comprador fica obrigado a cumprir ao rendeiro o contrato de arrendamento, sem contradição alguma.

Porém, estabelecem ainda as Ordenações que, em todo o caso em que o comprador possa desfazer o contrato de arrendamento ou aluguel, cumprindo o rendeiro ou alugador todo o seu interesse, assim por ganho como por perda, em razão do arrendamento, será o comprador obrigado a lhe cumprir e guardar seu arrendamento, ou alugar, sem outro algum embargo, nem contradição.

\subsection{Título XXVII}

\section{Das Sterilidades ${ }^{7}$}

Sob esse título, são previstas normas destinadas a reger as relações oriundas do contrato de arrendamento de prédio rural, na hipótese de ocorrência de perda parcial ou total das colheitas, por motivo de caso fortuito ou força maior. Ou, ainda, por culpa do lavrador.

$\mathrm{Na}$ hipótese de perda de frutos de alguma herdade, vinha ou outra semelhante, por motivo de cheias de rios, chuvas, pedra, fogo que as queimasse,

Terra, bem como na Lei n. 4.947, de 06.04.66, em seu Capilulo III, e no Dec. Lei n. 59.566, de 14.11.66, como arrendamento rural.

6. Trata-se aqui de contrato de hipoleca com garantia de arrendamento. A expressão "obrigou" teria o sentido de "onerou". A hipoteca estaria dependendo do arrendamento, este garantindo o pagamento do débito.

7. A culpa é tratada no Código Civil, Livro III, Título II, Direito das Obrigações. O caso fortuito e de força maior no art. 1.038 . 
seca, exército de inimigos, assuada de homens que as destruíssem, aves, gafanhotos, bichos ou outro semelhante caso, tolhendo todos os frutos, não ficava o rendeiro obrigado a dar coisa alguma da renda que se obrigou a dar.

$\mathrm{Na}$ hipótese de perda apenas parcial, ficaria à escolha do lavrador pagar o prometido, ou dar todos os frutos da herdade. Se a Sterilidade for em terra de pão, ${ }^{8}$ poderá o lavrador tirar para si a semente e os que mais sobejarem, dará ao senhorio da herdade arrendada.

Estabelecem, então, as Ordenações que, se em outros anos do mesmo arrendamento houver grande fartura na produção (abastança e uberdade não costumada), guardar-se-á a disposição do Direito Comum. ${ }^{9}$

Por outro lado, se os frutos viessem a se perder por culpa do lavrador, quer por lavrar mal a herdade, quer por motivo de ervas ou espinhos que nela nascerem, de maneira a consumir ou afogar os frutos, por si mesmo ou má guarda do lavrador, em tais casos ficará obrigado a dar o prometido.

\subsection{Título XXXVI}

Do que toma alguma propriedade de foro ${ }^{10}$ para si e certas pessoas, $e$ não nomeou alguém a ela antes da morte.

Neste título são fixadas normas relativas à sucessão do aforamento, no caso de morte do foreiro. Uma das normas estabelece que por morte do foreiro, se

\footnotetext{
8. Terra própria para o plantio de trigo. As disposições pertinentes das Ordenações só tinham, à época, aplicação a Portugal.

9. Direito Comum. Entendemos que o Direito Comum era o Direito Romano, conscntaneamente com o exposto na parte inicial deste trabalho.

10. Como se sabe, pelo contrato de aforamento ou enfiteuse, o proprietário de um imóvel, por ato entre vivos ou de última vontade, atribui a outrem o domínio útil de um imóvel, reservando o domínio direto para si, pagando a pessoa que adquirc o domínio útil, uma pensão ou foro anual certo c invariável. É também chamado emprazamento, foro c prazo. Tal contrato é perpétuo. Se por tempo determinado considera-se arrendamento e como tal deve ser regido. Os bens enfitêticos transmitem-se por herança e o proprictário do imóve] [ica com a sua propriedade, eis que transmite a posse, uso e gozo da coisa. Por ocasião da transferência do domínio útil de um foreiro para outro, há que pagar o chamado laudêmio. O foro, pois, pode ser considerado uma variedade de aluguel. É contrato bilateral, perfeito, consensual e scmpre oneroso. A cnfiteuse é regulada no Código Civil, Capilulo II, Tít. III, Direitos Reais sobre coisa allıcia. O aforamento de terrenos de marinha, pelo Dec. Lei n. 2.490, de 10.08.40, alterado pelos Decs. Lei n. 03.04.38, de 17.07.41, n. 4.120, de 21.02.42, n. 5.666, de 15.07.43 e n. 9.760, de 05.04.46. A cnfitcuse ou aforamento de imóveis rurais pode ser disciplinado sem qualquer exagero pelo Dircito Agrário. Basta lembrar seu grande prestígio no periodo medieval, para permitir a produção nas glcbas rurais.
} 
não tiver em vida nomeado sucessor, o herdeiro de seus bens in solidum fica nomeado ao foro, posto que outra nomeação não seja dele feita.

Se no testamento ficarem muitos herdeiros, mas não-ascendentes nem descendentes, todos se entendem nomeados ao foro. No entanto, se o foreiro tiver deixado muitos bens que possam atender ao quinhão de cada herdeiro, devem ser eles partidos entre os herdeiros, preservando-se o foro de ser partido entre muitos, evitando-se confusão na pensão.

Se não houver bens suficientes, poderá um deles haver o foro, satisfazendo aos outros na conformidade do entendimento geral ou da maioria. $\mathrm{Na}$ ausência de acordo, serão obrigados a vender ou escambar, requerendo primeiro ao senhorio, se o quer tanto por tanto, repartindo os herdeiros entre si, dita venda ou escambo. Se não venderem nem escambarem o foro, nem sendo tomado por qualquer deles no prazo de seis meses do óbito, ficará o foro devoluto ao senhorio se o quiser haver. Na falta de herdeiros, o foro será devoluto ao senhorio.

Se tiver filho legítimo, neto ou bisneto varão, ficará com o foro, ou filha ou neta não havendo varão.

Os filhos têm preferência aos netos. Se muitos os filhos, o maior dos filhos ou das filhas.

As Ordenações prosseguem nesse Título, dispondo sobre a nomeação dos sucessores do foreiro no contrato de aforamento, prescrevendo normas sempre minuciosas a respeito.

\subsection{Título XXXVII}

Das nomeações que se fazem dos prazos, em que casos se podem revogar.

Este Título dispõe sobre a nomeação que pode o foreiro fazer, por ato entre vivos ou causa mortis, de outras pessoas para substituí-lo como foreiro, no contrato de aforamento celebrado com o senhorio.

Repetindo, pois, o Título em questão, estabelece minuciosas regras a presidir a nomeação pelo foreiro da pessoa que irá sucedê-lo no contrato de aforamento.

Uma das normas estabelece que, se o foreiro dispuser em vida em favor de outra pessoa, a título de dote, não poderá nomear outra, mesmo que reserve 
a si o usufruto. A beneficiária é que poderá dispor da coisa. Por outro lado, se no contrato de aforamento tiver sido dado ao foreiro poder para nomear uma pessoa, nomeada esta, não poderá mais revogar a nomeação nem fazer outra para revogar a primeira. Se feita, não valerá em face ao direito adquirido da primeira, ainda que não seja sabedora da nomeação. Outra regra estabelece que todas as estabelecidas no Título sobre nomeação de foreiro por sucessão e respectiva revogação terão aplicação não-só quando o poder de nomear for dado em contrato, como em testamento ou última vontade.

\subsection{Título XXXVIII}

Do foreiro que alheou o foro com autoridade do senhorio ou sem ela.

Este Título cuida da proibição de venda, escambo ou doação da cousa aforada, entre elas as herdades, " sem consentimento do senhorio.

Ao senhorio é assegurado o direito de preferência, razão pela qual deve ser notificado da intenção do foreiro, que declarará o preço ou cousa que lhe dão pelo imóvel, para que se manifeste tanto por tanto.

Tal regra prevalece quer na hipótese de venda voluntária, por vontade do foreiro, quer na necessária, por mandado e autoridade da Justiça.

Ao senhorio, se não quiser declarar logo se quer a cousa, se esperará pelo prazo de trinta dias a partir do dia em que foi requerido. E decorrido esse prazo, poderá o foreiro vender ou escambar, sem mais espera por resposta ou pagamento do preço. Pagará, no entanto, ao senhorio a quarentena ou o estabelecido em seu contrato.

Se declarar, nesse prazo, que a quer pelo preço, pagando-lhe logo este preço, have-la-á sem necessidade de haver quarentena. Se o preço não for pago dentro do prazo, poderá o foreiro vender a cousa aforada, sem embargo da declaração.

Será nenhuma a venda feita sem atendimento dessas normas, perdendo o foreiro seus direitos e tudo será devoluto e aplicado ao senhorio. Se este não quiser, poderá demandar e constranger o foreiro ao cumprimento de seu foro.

11. Grande propricdade rúslica conslituída de terreno de cultivo e habilação (Lello Universal Novo Dicionário Enciclopédico - Luso-Brasileiro - Porto) 
Nesse Título são ainda estabelecidas normas relativas à posição do foreiro em relação ao senhorio, na hipótese de venda e falecimento posterior do adquirente.

Há também nele remissão a hipóteses previstas no de n. XXXVI, já analisado.

\subsection{Título XXXIX}

Do foreiro que não-pagou pensão em tempo devido e como purgará a mora.

O não-pagamento pelo foreiro de foro ou pensão por três anos, cumpridos e contínuos, implicará no perecimento de seu direito sobre a cousa aforada em favor do senhorio, se este o quiser.

Cairá, pois, em comisso, do qual não será relevado, ainda que queira pagar depois todo o seu débito, salvo se expressamente aprouver ao senhorio aceitar a purgação e relevá-lo do comisso em que caiu.

$\mathrm{Na}$ hipótese de possessões eclesiásticas concedidas a pessoas eclesiásticas ou leigas, o prazo a resultar no comisso é menor: dois anos cumpridos e contínuos.

O foreiro poderá, neste caso, purgar a mora oferecendo ao senhorio as pensões devidas em qualquer tempo antes de sua citação em juízo ou depois de citado, antes de contestada a lide.

Esta faculdade, conferida ao foreiro de bens eclesiásticos, resulta de ser mais breve o tempo em que cai em comisso por não-pagamento do foro (dois anos), enquanto que para o foreiro de bens profanos é de três anos.

Em relação aos bens eclesiásticos se guardava o Direito Canônico e aos profanos o Direito Civil.

\subsection{Título XL}

Que se não aforem casas senão a dinheiro.

Este Título encerra proibição no sentido de se aforarem casas ou terras mediante pagamento em espécie da pensão ou foro, isto é, pão, vinho, azeite ou semelhantes, mas somente em dinheiro. 
Não é extensiva, porém, ao pagamento em aves. Este é permitido. Os contratos que infringirem tais normas serão tidos como nenhuns e de nenhum efeito.

\subsection{Título XLI}

Que os foreiros dos bens da Coroa, Morgados, Capellas ou Commendas, não dêm dinheiro nem outra cousa aos senhorios, por Ihes aforarem ou novarem.

Este Título estabelece que nenhuma pessoa com terras da Coroa do Reino de Portugal, bem como administradores de Capellas, Morgados e Comendadores, recebam dinheiro ou qualquer vantagem dos foreiros para lhes fazer contratos de aforamento ou inovar os já feitos.

A infringência da norma resulta na aplicação de penas. O que receber dinheiro pagará o que assim receber e mais outro tanto; o que der, perderá o que deu e pagará de pena outro tanto, cabendo a metade para quem acusar o fato e a outra para os cativos. $\mathrm{O}$ contrato, por outro lado, ficará nenhum e de nenhum vigor, para tornar-se devoluto ao senhorio o imóvel, a fim de o aforar de novo, a quem quiser. Como se vê, as penalidades tinham caráter bilateral. A prática vedada tem analogia modernamente com as luvas, representada por vantagens, via de regra em dinheiro, que se estabelece em favor da parte contratante para a transferência ou renovação de contratos, notadamente de locação.

\subsection{Título XLII}

Que não sejam constrangidas pessoas algumas a pessoalmente morarem em algumas terras ou casais. ${ }^{12}$

Neste Título, se proíbe sejam constrangidas pessoas a morarem e povoarem casais e terras, bem como fossem oprimidas ou presas por tais motivos. Em decorrência do procedimento vedado, muitas mulheres não conseguiam se casar

12. Nítida a preocupação nesse Título, com a liberdade da pessoa humana. Aliás, as Ordenações, nos Títulos analisados, demonstram sempre preocupação por valores tais como o interessc comum e a clignidade da pessoa humana. 
por não encontrarem quem as quisesse. Dizia-se que eram ascripticias, isto é, pessoas obrigadas a morar em determinados lugares.

\subsection{Título XLIII}

\section{Das Sesmarias}

Em 26 de junho de 1375, no Reinado de D. Fernando I, foi aprovada a Lei das Sesmarias, dada a publicação em Santarém. Tal lei foi incorporada às Ordenações Afonsinas e destas passou para as Manuelinas e finalmente para as Filipinas.

Seu intuito era o de evitar a carência e carestia dos gêneros alimentícios; 0 êxodo de trabalhadores rurais para outras atividades mais suaves; 0 desenvolvimento da criação de gado e, principalmente, a oscilação do preço das terras, desequilibrando a oferta com a procura.

Procurou, outrossim, através de preceitos impositivos, tornar efetiva a cultura das terras, sem tolerância para com os ausentes e omissos. A agricultura era indispensável à produção do pão e vinho. Os senhores das terras ou as cultivavam, ou eram constrangidos a transmiti-las por enfiteuse ou arrendamento, para serem trabalhadas mediante paga de pensão ajustada ou, na falta de ajuste, arbitrada por louvados em via judicial. Em caso de resistência, as terras lhes seriam tiradas e entregues a quem as quisesse cultivar pela renda e tempo convencionados entre o agricultor e a Justiça.

Para esse desiderato, eram comissionados em cada vila ou cidade dois homens bons entre os melhores cidadãos. Se a decisão resultasse em empate, nomearia o juiz, terceiro louvado para desempate. Aos membros dessa junta se denominaram juizes das Sesmarias ou sesmeiros. O vocábulo adveio de Sesmo, equivalente primitivo de Sexto ou Seximum, formado na época romana. Significava a sexta parte dos frutos. 
Consoante decorre desse Título das Ordenações Filipinas,

"Sesmarias são propriamente as dadas de terras, casaes ou pardieiros, que foram, ou são de alguns senhorios, e que já em outro tempo foram lavradas e aproveitadas, e agora o não são" 13

Prescreve ela ainda:

As quais terras e os bens assim danificados $e$ destruídos podem e devem ser dados de Sesmarias, pelos sesmeiros, que para isto foram ordenados. E a nós somente pertence dar os ditos sesmeiros, e os por nos lugares onde houver terras ou bens de raiz de que sesmaria se devam dar. E as terras onde se as Sesmarias houverem de dar, forem foreiras ou tributárias a nós ou à Corôa de nossos Reynos, que se os foros e tributos arrecadem para nós, quer para outrem, a que os tenhamos dado, costumamos dar por sesmeiros os nossos Almoxarifes dos lugares ou Almoxarifados onde os tais bens ou terras estão"

Em seguida são fixadas normas sobre o procedimento a ser adotado para obrigar o sesmeiro a dar cultivo à terra ou para dele tirar e dar a outrem.

Estabelece-se, então, que os sesmeiros verifiquem a antes de dar a terra, quem são os seus senhores, fazendo-os citar juntamente com suas mulheres, e assinando-lhes tempo conveniente para virem dizer a razão de não darem as terras de Sesmarias. Não é suficiente a citação dos enfiteutas ou outros possuidores. Os senhorios ouvidos junto com os pretendentes, demonstrada a razão pela qual não se devam dar as terras, estas não se darão. Se nada alegarem ou provarem, e não atenderem à citação, ser-Ihes-á assinado prazo de um ano, para que as lavrem ou

13. Casaes = Casas ou oficinas rústicas entre terras de granjeio; pequeno pedaço de terra próximo, mas nāo-anexo à liabilação do respeclivo dono. - Pardieiro = Casas $\mathrm{cm}$ ruinas: colíícios vellıos (Dicionário Lello Universal, antcriormente citado). 
aproveitem, vendam, emprazem ou arrendem a quem as possa aproveitar ou lavrar. Se nada fizerem, passado o dito ano, os sesmeiros darão as ditas Sesmarias a quem as lavre e aproveite. Pouco importa que os senhorios sejam Grandes e Fidalgos.

$\mathrm{Na}$ impossibilidade de os sesmeiros identificarem os senhores das terras, deverão ser apregoados nos lugares onde se encontrem, que se darão em Sesmaria, declarando onde estão e as suas confrontações.

Preceito dos mais relevantes é o constante deste Título e dirigido aos sesmeiros para que não dêem maiores terras a uma pessoa de Sesmaria, que as que razoavelmente parecer que no dito tempo poderão aproveitar.

Em tal preceito se pode vislumbrar a idéia da função social da propriedade, que inspirou por sua vez a do módulo ou propriedade familiar na Lei Agrária brasileira. ${ }^{14}$

O não-aproveitamento das terras pelos sesmeiros dará margem à execução das penas, com a entrega das mesmas a outros, que as aproveitem no tempo assinado e sob a dita pena.

Nesse Título ainda é prevista a possibilidade de defesa, formando-se autos escritos por tabelião ou escrivão. Um resumo dos mesmos deverá constar nas Cartas de Sesmarias para se saber se foram bem dadas ou-não. Qualquer contenda será conhecida ou pelos almoxarifes ou pelos juizes ordinários dos lugares onde estiverem os bens, quer se trate de terras foreiras ou tributárias da Coroa, quer não.

Há ainda normas no sentido de constranger os administradores ou mordomos de terras pertencentes a Capellas, Hospitais, Albergarias ou Confrarias, inaproveitadas, no sentido de que as aproveitem, fixando-se tempo para isso e impondo-lhes penas.

14. Salvo melhor apreciação, nesse disposilivo teríamos o embriāo do atual módulo, previsıo na legislação agrária, a partir da Lei n. 4.504, de 30.11.64. Com efeito, a idćia nuclear desse preccito. como de reslo a do chamado módulo, tal como previsto no art. $4^{\circ}$. da Lei n. 4.504, de 30.11 .64 . é a de estabelecer a justa medida. No estabelecimento dessa justa medida se acha implicito um valor cconômico e um valor social. O ideal é que cada família disponha de área agricultável que, com sua força de trabalho e ajuda de terceiros em caráter eventual, possa satis ‘atoriamente se desenvolver, dai tirando o necessário não-só para a sua subsistència como para sua melhoria na escala social c cconômica. Tal o conccito atual, obviamente explícito, da justa medida enunciada $\mathrm{cm}$ a norma contida nas Ordenaçōes. Não dar nem mais nem menos terra que o sesmciro pudesse trabalhar. 
As Ordenações prevêm ainda a hipótese de os senhorios das terras danificadas estarem homiziados fora do Reino. Nesse caso, serão requeridas suas mulheres, fixando-se tempo para que cheguem ao seu conhecimento. Se não vierem nem mandarem procurador, será dado curador aos bens e assinado o tempo de um ano para que os aproveitem. Caso contrário, serão dados em Sesmaria a quem os aproveite.

Há ainda um tópico deste Título que alude à atitude de alguns senhorios que, para não perderem suas terras, cultivam apenas algumas oliveiras. Lavram um pedaço de terra e deixam todo o resto. Há ainda os que deixam perder as vinhas, tornando-as em terra folgada, isto é, não-semeada, e os que deixam perder seus olivais por não quererem adubá-los, nem roçá-los. Os donos de tais bens deverão ser requeridos e assinado o termo para que lavrem, semeiem, rocem e adubem os olivais e vinhas. Se não o fizerem, passado o termo (prazo) serão dadas em Sesmaria.

Outras normas dispõem ainda sobre a destinação de terras que jamais foram aproveitadas ou lavradas, em Sesmarias, para proveito comum e geral de todos, desde que na terra haja abastança de pão e de outros frutos. Os interessados em tais terras deverão requerer ao procurador do lugar onde estiverem. Se úteis ao bem comum, não serão dadas em Sesmarias.

Encontramos ainda recomendação de não destinar às Sesmarias os matos próprios ou pouzios úteis aos assentamentos de quintas, casais e outras destinadas a pastos, criações e logramento dos moradores dos lugares onde estão e não devem ser destinados a Sesmarias.

Outras normas disciplinam a não-destinação a Sesmarias de vales e ribeiras que não sejam da Coroa nem reservados pelos reis anteriores. Caso contrário, os moradores prejudicados poderão demandar seus direitos.

Outro preceito estabelece sobre as Sesmarias de terras tributadas, e em terras isentas, as quais devem ser dadas como são, não se pondo outro tributo se já tributadas. Este não teria validade.

Prescrição também deste Título recomenda não se destinem terras para lavoura se forem fracas, que não possam elas durar mais que três anos. $O$ mesmo deve ser feito se a queima e corte de matas ou árvores possam causar dano geral ou a alguns que possuam criação. Se, no entanto, os juízes, procuradores e vereadores acharem que poderão ser dadas para roças, há que se cuidar para que não haja dano aos moradores dos lugares. 
Finalmente, sob esse Título se encontra um apelo aos prelados, mestres, priores, comendadores e fidalgos que já tenham terras, para que não se apropriem nem para si nem para suas ordens, igrejas ou mosteiros, dos casais, quintas e terras que ficarem ermas, se não forem suas e as deixem dar aos sesmeiros de Sesmarias.

Há ainda uma proibição no sentido de que sejam colocados nas Cartas de Sesmarias preceitos no sentido de que não sendo aproveitadas no tempo fixado, fiquem elas para a ordem ou igreja, ou aos senhores delas. E isto porque, nessa hipótese, deverão ser novamente destinadas para Sesmarias. A norma proibida será tida como não-válida.

\subsection{Título XLV}

Do que da herdade a parceiro de meias, ou a terço, ou quarto, ou a arrenda por certa quantidade. ${ }^{15}$

Nesse passo estabelecem as Ordenações que se alguma pessoa der a outrem sua vinha ou herdade a lavrar de meias, terço ou quarto, ou como se consertarem por tempo certo, que seja menos de dez anos, e durante o dito tempo se finar algum deles, o que vivo ficar, e os herdeiros do defunto não sejam obrigados a manter e cumprir o contrato, porque o contrato feito nesta forma segue a natureza e qualidade do contrato de parceria e assim deve ser julgado de um como de outro.

Porém, se ao tempo da morte de cada uma das partes principais o lavrador tivesse já a herdade laviada, a vinha podada, ou feito alguma outra obra de adubio, passará o contrato aos herdeiros por esse ano. E assim os herdeiros, como a parte sobreviva, serão obrigados a mantê-lo por esse ano somente, que já era começado de adubar e mais não.

Quando o senhor da vinha ou herdade a desse de meias, terço ou quarto, por tempo de dez anos, ou mais, passará esse contrato aos herdeiros, porque tal contrato assim feito não segue a natureza e condição do de parceria, mas constitui outra espécie de contrato. ${ }^{16}$

15. A parceria ou contrato de parceria é uma associação, não propriamente uma socicdade. Os parceiros são compartes ou co-interessados, mas não-sócios. São associados. Não tenı̀ direilos tão amplos, nem obrigações idênticas a dos sócios.

16. Contrato de enfiteuse ou aforamento. 
Em todo o caso em que o senhor da vinha ou herdade a der de renda por certa quantidade de pão, vinho, azeite ou dinheiro, por muito ou pouco tempo, sempre o contrato passa aos herdeiros por ser contrato de arrendamento diverso do de parceria e, portanto, deve por outra maneira ser julgado.

Por outro lado, manda-se que todos os lavradores que trouxerem herdades de parceria e meias a terço ou quarto, ou a certa outra quota, não tirem nem levantem o pão da heira ${ }^{17}$ até o primeiro fazer saber ao senhorio ou a quem seu cargo tiver no lugar ou termo. E não sendo aí, o tirem e meçam perante duas testemunhas sem suspeita. E tirando-o de outra maneira, a terra será estimada por dois ou três homens bons juramentados, e do que estimarem que a terra poderia dar, pagarão a parte que haviam de dar em dobro, para o senhorio ou o que lhe deu a terra a lavrar, sem mais lhe ser dada outra pena criminal, nem cível.

\subsection{Título LXIX}

Que se não façam arrendamentos de gados ou colmêas.

Sob esse Título, prescrevem as Ordenações a seguinte e curiosa proibição:

Por quanto somos informados, que se fazem muitos contratos, por que se dão bois e outro gado por certos anos de renda por certa pensão em cada um ano; ora os bois, ou gado vivam, ou morra no dito tempo, e algumas vezes se põem nos contratos, que acabado o tempo do arrendamento, Ihe tornem os bois, ou gado, ou sua valia, se forem mortos; e outras vezes, que acabado o tempo do arrendamento, Ihe não sejam mais obrigados tornar os ditos bois, nem gado; e assim se fazem outros contratos, por que dão certas cabeças de gado, como vacas, porcos, cabras, ou colmêas, por certo tempo, e

17. A expressão pão da heira corresponde ao trigo em grão exposto na eira. A eira corresponde ao terreiro dos nossos sítios e fazendas. A disposição das Ordenações, no caso, tinha aplicação em Portugal ou províncias que cultivavam o trigo. 
que acabado o tempo, lhe dêem tantas cabeças mais das que lhe deram, ora a criação, ou gado, ou colmêas, que Ihe dão, vivam ou morram, ou cresçam, ou se diminuam.

E porque os tais contratos são ilícitos por Direito, defendemos que se não façam, e fazendo-se, os havemos por nenhuma e de nenhum efeito e vigor. E quem os ditos bois, gado ou colmêas, por cada um dos ditos partidos, der, perca e gado e colmêas que assim der, se ainda forem vivos, ao tempo, quer por isso for demandado, a metade para quem o acusar, e a outra para nossa Camera." 18

\section{Conclusões}

Concluindo, as normas constantes dos títulos enunciados anteriormente constituem, salvo melhor juízo, normas de Direito Agrário, abrangidas no conceito de Direito Agrário, enunciado inicialmente. São as normas de Direito Agrário, contidas no Livro IV. das Ordenações Filipinas.

Mesmo na parte relacionada com a função social da propriedade, ainda que não se possa concluir que nossos antepassados portugueses tivessem do assunto o conceito que dele atualmente se tem, inequívoco nos parece, contudo, o interesse de ordem econômico-social, que ditaram aquelas normas. Sobretudo, procurando assegurar a efetiva ocupação e cultivo das terras agricultáveis, em proveito de sua finalidade intrínseca, a produção agrícola. Até como apoio logístico para assegurar a produção do pão para alimentar os soldados no campo de batalha. É o que deflue da leitura e análise das normas catalogadas nos títulos enunciados anteriormente, notadamente os relativos às Sesmarias e aos contratos agrários (arrendamento e parceria). Não refluem, em verdade, de tais normas, as funções social e econômica da propriedade, em toda sua plenitude?

18. Em França e em outros paises tais contratos eram admitidos. (Cód. Civil francês, arts. 1.800 a 1.831). Em França é denominado Bail à cheptel (sociedade de animais dados à perda ou ganhos). Entre os portugueses a prática denominava-se "dar animais ao ganho" Proibiu-se em Portugal por entendê-lo como modalidade de usura do rico contra o pobre. Ordenações - Candido Mendes de Almeida $14^{\mathrm{a}} \mathrm{ed}$. Rio, 1870. 
Outro aspecto que se destaca na análise de direito cristalizado nas Ordenações é o preservar a dignidade humana, prescrevendo práticas abusivas à mesma, quer por ato da autoridade, quer dos particulares. É a ênfase dada ao bem comum. Tais os valores pelos quais a luta permanece aberta e constante também em nossos dias.

Muito embora em relação a alguns Institutos possam ser encontradas normas peculiares, algumas curiosas e mesmo sem aplicação nos dias atuais, boa parte delas permanece viva até hoje. Subsistem no Direito Agrário atual, certamente por espelharem soluções cristalizadas ao longo do tempo, fruto do engenho e arte humanos, aplicados aos seus mesmos e permanentes problemas.

São Paulo, agosto de 1999.

4. Bibliografia

ALMEIDA COSTA, Mário Júlio. "História do Direito Português" Ed. Almedina, Coimbra, 1999.

FERREIRA BORGES. Jurisprudência, apud Ordenações, Cândido de Almeida, Rio, 1870.

Lello Universal Novo Dicionário Enciclopédico Luso-Brasileiro - Porto.

Ordenações do Reino Edições do Século XVI - Tito de Noronha Ernesto Chardron Porto 1871. 



\section{CODIGO PHILIPPINO \\ OC: \\ ORDENAÇOES E LEIS \\ Int}

BELNO DE PQBTUEAL

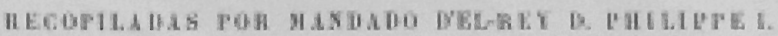

DECIMA-QUARTA EDIC̈R̆O.

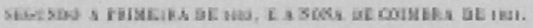

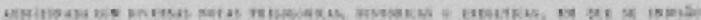

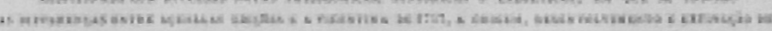

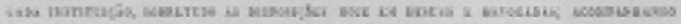

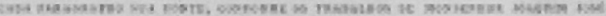

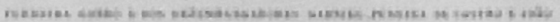

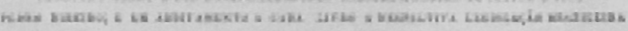

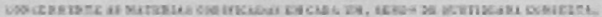

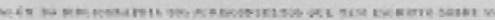

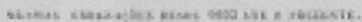

Fus

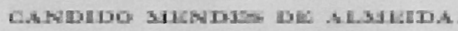

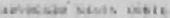

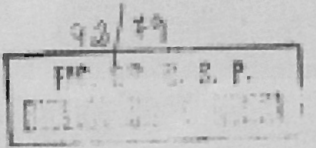

FIT DE TAMEIFO

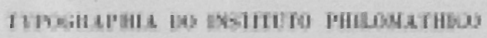

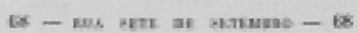

$18 x+1$

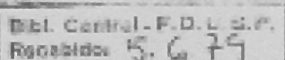

O Código Filipino: ordenações e leis do Reino de Portugal 



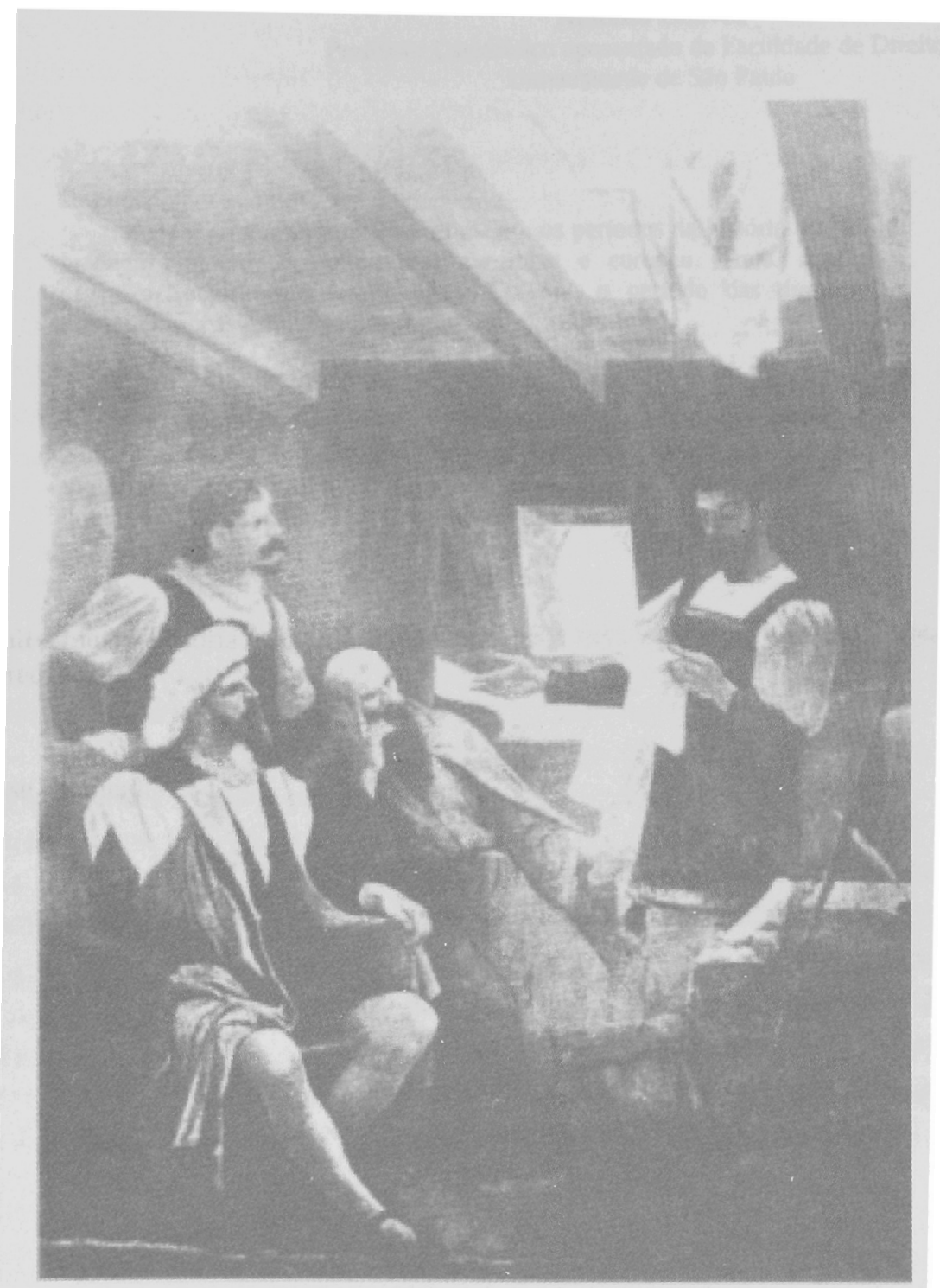

O primeiro capítulo da história-pátria. Quadro de Aurélio, no antigo Palácio Monroe 